\title{
Effect of date of transplanting and mulching on growth, yield and quality of onion (Allium cepa L.) cv. Nasik Red
}

\section{Bhagauti Prasad, Sutanu Maji" and Kamal Ram Meena}

Department of Applied Plant Science (Horticulture), Babasaheb Bhimrao Ambedkar University (A Central University), Vidya Vihar, Rae Bareli Road, Lucknow-226025 (U.P.), INDIA

*Corresponding author. E-mail: majisutanu@gmail.com

Received: April 27, 2016; Revised received: September 25, 2016; Accepted: January 10, 2017

Abstract: A field experiment was conducted during rabi season of 2014-2015 at Department of Applied Plant Science (Horticulture), Babasaheb Bhimrao Ambedkar University, Lucknow-226025 (U.P.) India to find out the effect of different dates of transplanting and mulching on growth, yield and quality of onion (Allium cepa L.) cv. Nasik Red. There were 16 treatments comprising 4 dates of transplanting $\left(15^{\text {th }}\right.$ November, $1^{\text {st }}, 15^{\text {th }}$ and $30^{\text {th }}$ December $)$ and 3 mulching (saw dust, rice husk and wheat straw) while, without mulching as control and laid out under two factor RBD with three replications. The study clearly revealed that there were significant effects of all treatments on vegetative growth, yield and quality attributes of onion. Plant height $(65.34 \mathrm{~cm})$, number of leaves per plant $(8.89)$, length of leaves $(56.07 \mathrm{~cm})$, neck thickness $(18.75 \mathrm{~mm})$, yield $(5.166 \mathrm{~kg} / \mathrm{plot}$ and $387.46 \mathrm{~g} / \mathrm{ha})$ were found maximum at $1^{\text {st }}$ December planting with wheat straw mulching $\left(T_{7}\right)$. The best quality bulb in respect of maximum neck thickness $(12.35 \mathrm{~mm})$, basal diameter (13.61. $\mathrm{mm})$, diameter of bulb $(54.41 \mathrm{~mm}$ polar and $64.15 \mathrm{~mm}$ equatorial), length of bulb $(65.17 \mathrm{~mm})$, number of scales per bulb $(9.24)$, bulb moisture $(85.06 \%)$ T.S.S. (13.84 ${ }^{\circ}$ Brix), ascorbic acid (10.47 $\mathrm{mg} / 100 \mathrm{~g})$, total sugars $(10.39 \%)$ etc. were also obtained when mulching was done with wheat straw and transplanted on $1^{\text {st }}$ December $\left(T_{7}\right)$ followed by $T_{6}$ (planted on $1^{\text {st }}$ December and mulching with rice husk). The study clearly concluded that i.) mulching is good for production of onion, ii.) late transplanting on $30^{\text {th }}$ December showed very poor performance irrespective of mulching and iii) transplanting on $1^{\text {st }}$ December and mulching with wheat straw was the best combination for getting good quality yield of onion.

Keywords: Date of transplanting, Mulching, Onion, Quality, Yield

\section{INTRODUCTION}

Onion (Allium cepa L.) is one of the most important commercial bulbous vegetable as well as spice crops. According to Hasegawa et al. (2001), it is originated at Central Asia and is cultivated in many countries around the world. Onion is the second most important vegetable crop after tomatoes in terms of income generation (Griffiths et al., 2002; Mallor et al., 2011). The name "wild onion" is applied to a number of Allium species but $A$. серa is exclusively known from cultivation and its ancestral wild original form is not known, although escapes fruit cultivation have become established in some regions. However, Zohary and Hopf (2000) stated that "there are doubts whether the A. vavilovii collections tested represent genuine wild material or only feral derivatives of the crop". It is a short duration and quick growing herb having various uses such as vegetables, spices and for medicines. It promotes appetite and is useful against malaria, night blindness which also lowers blood pressure (Perane, 2001). India is the second largest producer of onion next to China accounting for 20 percent of the world area and 10 percent of the world production having annual production of $18736^{\prime} 000$ MT from $882^{\prime} 000 \mathrm{HA}$ area and productivity of $21.2 \mathrm{MT} / \mathrm{HA}$. The major onion growing states of India are Maharastra, Karnataka, Madhya Pradesh, Andhra Pradesh, Bihar, Gujarat, Punjab and Tamil Nadu (Anonymmous, 2014). At present, Maharashtra is the leading state in onion production having an area of 1.21 lakh hectares with production of 14.23 lakh MT (Anonymmous, 2015). Nasik district alone contributes approximately $30 \%$ of production of state and $70 \%$ of total onion exported from India is from Maharshtra state.

Allium is characterized by the presence of remarkable $\mathrm{S}$ containing compound (allyl propyle di sulphide) which gives it a distinctive smell and pungency. It also has an antibacterial, antiseptic (Duke and Ayensu, 1994) and antifungal characteristics. Onion bulb is a rich source of minerals like phosphorus, calcium, carbohydrates and protein (Aykroyd, 1963). Bulb juice is used as smelling agent for hysterical fits and faintness. It is a favourable because of its volatile flavours (containing sulphur) released during tissue disruption (Abbey and Joyce, 2004). Onion is used in the stomach disorder and prevention the children to 'lu' and 'Kalra' in summer season. Small sized onions 
are more nutritive than large sized onions. The performance of an onion cultivar depends on the interaction between genotype and the environment (Jilani and Ghaffoor, 2003). This interaction mainly determines cultivar selection for a specific area. On the other hand, agronomic practices such as sowing date, fertilization, irrigation and plant population among others, also have an effect on the growth, yield and quality of onion bulbs (Brewster, 2008). In other words, under favorable conditions, higher yield may be obtained in a shorter growing season. So, it is very important to find a suitable time of planting for higher yield and quality. Planting at proper time has a pronounced effect on the growth, yield and quality production of onion (Singh and Korla, 1991), but, it may vary region to region. Research findings from different countries suggested that time of planting and varieties/accessions have a profound effect on the growth and yield of onion. Another important practice is mulching which helps to retain soil moisture and helps in control of temperature fluctuations, improves physical, chemical and biological properties of soil, as it adds nutrients to the soil and ultimately enhances the growth and yield of crops (Maji and Das, 2008 a, b). Mulching may be natural or artificial. It may be natural or artificial. For the past decades people are more concern about the organically produced foods (Maji, 2013). So, use of natural organic mulching is now getting popularity. Mulching conserves soil moisture from 2.1-2.8\% more than non-mulched one. Mulching also manage weeds which are serious problem in onion which limits the crop yield and decreased profits. Mulching using paddy straw, saw dust, neem leaves were observed to suppress weed growth effectively in onion (Umar et al, 2000). Keeping this in view, the present experiment was carried out to study the effect of different dates of planting and organic mulching on growth, yield and bulb quality of onion (Allium cepa L.)

\section{MATERIALS AND METHODS}

The experiment was conducted using onion cultivar Nasik Red during the rabi season of 2014-2015 at the Horticulture Research Farm, Department of Applied Plant Science (Horticulture), Babasaheb Bhimrao Ambedkar University, Lucknow (Utter Pradesh) India to find out the effect of date of transplanting and mulching on growth, yield and quality of onion. A total of sixteen treatments including control were laid out in Factorial (two factors) Randomized Block Design (RBD) with three replications. Experimental site was at $80^{\circ} 52^{\prime}$ East longitude and $26^{\circ} 50^{\prime}$ North latitude and altitude of 123 meter above mean sea level (MSL) with dry subtropical climate $\left(29-45^{\circ} \mathrm{C}\right.$ in summer and minimum temperature from $2^{0} \mathrm{C}$ to $12^{\circ} \mathrm{C}$ in winter and relative humidity of $50-77 \%$ ) having sandy loam soil slightly alkaline in reaction. The treatments included 4 dates of planting $\left(15^{\text {th }}\right.$ November, $1^{\text {st }}, 15^{\text {th }}$ and $30^{\text {th }}$
December) and 3 mulching (saw dust, rice husk, wheat straw) while without mulching as control. Mulching materials were collected from local market. Wheat straw was chopped and the mulch materials were spread over soil at least $1.5-2$ inch thickness according to the respective treatments. Seeds of the onion (Allium сера L.) cv. Nasik Red were collected from NHRDF Centre, Deoria (U.P.). Bulbs of Nasik Red are attractive dark red in color. It is very popular among frames in North India because of its attractive bronze red and better performance, mature in 110-120 days after transplanting and thus, recommend for cultivation in Northern, Central and Western India during Rabi season. Seedlings were raised in nursery beds, $1.0 \mathrm{~m}$ wide and of convenient length nicely prepared by mixing fully decomposed FYM (3-4 kg/m ${ }^{2}$ ). Nursery beds were raised $15-20 \mathrm{~cm}$ in order to allow proper drainage of water. The seeds were sown in rows at $10 \mathrm{~cm}$ distance at shallow depth, $1.0 \mathrm{~cm}$ apart and then lightly covered with finely sieved leaf mould. Healthy seedlings of 10 to $15 \mathrm{~cm}$ height with 3 to 4 leaves were transplanted. The data were recorded for vegetative growth, yield and quality attributes control such as, plant height $(\mathrm{cm})$, number of leaves per plant, length of leaves $(\mathrm{cm})$, neck thickness $(\mathrm{mm})$,yield per plot $(\mathrm{kg})$, yield per hectare $(\mathrm{q})$, neck thickness $(\mathrm{mm})$, basal diameter $(\mathrm{mm})$, polar diameter $(\mathrm{mm})$, equatorial diameter $(\mathrm{mm})$, length of bulb $(\mathrm{mm})$, number of scales per bulb, bulb moisture (\%)T.S.S. ( ${ }^{\circ}$ Brix), ascorbic acid (mg/100g), total sugars (\%), reducing sugar (\%), non-reducing sugar $(\%)$ etc. worked out from each pot. The chemical analysis was done following the standard methods as stated by AOAC (2000). The collected data was statistically analyzed by following the standard procedure of ANOVA as stated by Panse and Sukhatme (1985) and the treatment effects were compared at $5 \%$ level of significance.

\section{RESULTS AND DISCUSSION}

Effect of date of transplanting and mulching on vegetative growth characters of onion: The experimental results (Table 1) showed that the use of different date of transplanting and mulching increased plant height significantly. Among the treatments without mulching, it was seen that first date of transplanting at $15^{\text {th }}$ November $\left(\mathrm{T}_{4}\right)$ showed the highest $(62.20 \mathrm{~cm})$ plant height at 30 days after transplanting (DAT). However, the plant height was found maximum under treatment $\mathrm{T}_{6}$ at $30 \mathrm{DAT}$ among the all treatments combining with mulching. While, at 60 and $90 \mathrm{DAT}, \mathrm{T}_{7}$ (transplanting at $1^{\text {st }}$ December with chopped wheat straw mulching) recorded the highest plant height $(54.15 \mathrm{~cm}$ and $65.34 \mathrm{~cm}$, respectively). The minimum plant height was noted at 30,60, and 90 DAT (23.97 $\mathrm{cm}, 50.99 \mathrm{~cm}$ and $62.20 \mathrm{~cm}$, respectively) in the untreated control. The maximum number of leaves per plant at 30 DAT was observed in the treatment $T_{6}$ (first 
Bhagauti Prasad et al. / J. Appl. \& Nat. Sci. 9 (1): 94 -101 (2017)

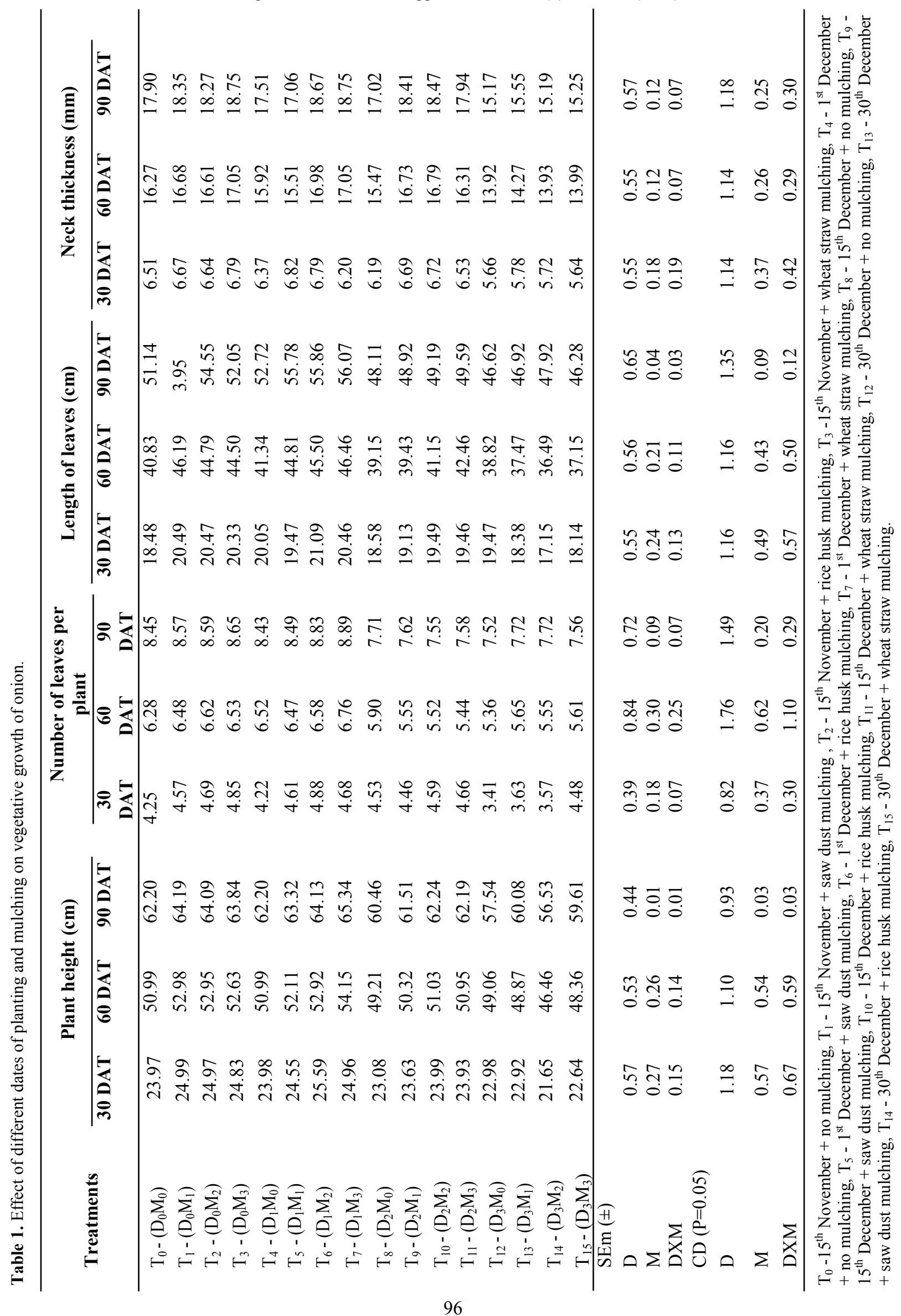


Bhagauti Prasad et al. / J. Appl. \& Nat. Sci. 9 (1): 94 -101 (2017)

Table 2. Effect of various dates of planting and mulching on bulb yield and physical quality of onion.

\begin{tabular}{|c|c|c|c|c|c|c|}
\hline Treatments & $\begin{array}{c}\text { Yield } \\
\text { Per plot } \\
\text { (kg) }\end{array}$ & $\begin{array}{l}\text { Yield } \\
\text { (q/ha) }\end{array}$ & $\begin{array}{c}\text { Basal } \\
\text { diameter } \\
\text { of bulb } \\
(\mathbf{m m})\end{array}$ & $\begin{array}{c}\text { Polar } \\
\text { diameter of } \\
\text { bulb } \\
(\mathrm{mm})\end{array}$ & $\begin{array}{c}\text { Equatorial } \\
\text { diameter } \\
\text { of bulb } \\
(\mathrm{mm})\end{array}$ & $\begin{array}{r}\text { Length of } \\
\text { bulb }(\mathrm{mm})\end{array}$ \\
\hline $\begin{array}{lr}\mathrm{T}_{0}-15 \text { th } & \text { November }+ \text { no } \\
\text { mulching } & \end{array}$ & 4.965 & 372.34 & 11.36 & 47.24 & 59.19 & 59.96 \\
\hline $\begin{array}{l}\mathrm{T}_{1}-15 \text { th November }+ \text { saw dust } \\
\text { mulching }\end{array}$ & 5.121 & 384.05 & 13.24 & 53.33 & 62.74 & 62.87 \\
\hline $\begin{array}{l}T_{2}-15 \text { th November }+ \text { rice husk } \\
\text { mulching }\end{array}$ & 5.072 & 380.41 & 13.13 & 53.15 & 63.21 & 63.85 \\
\hline $\begin{array}{l}\mathrm{T}_{3}-15 \text { th November }+ \text { wheat } \\
\text { straw mulching }\end{array}$ & 5.145 & 385.90 & 13.11 & 53.18 & 63.60 & 64.47 \\
\hline $\begin{array}{l}\mathrm{T}_{4}-1 \text { st December }+ \text { no mulch- } \\
\text { ing }\end{array}$ & 5.015 & 376.11 & 11.65 & 50.96 & 60.21 & 61.17 \\
\hline $\begin{array}{l}\mathrm{T}_{5}-1 \text { st December }+ \text { saw dust } \\
\text { mulching }\end{array}$ & 5.119 & 383.90 & 12.66 & 54.31 & 64.09 & 64.47 \\
\hline $\begin{array}{l}\mathrm{T}_{6}-1 \text { st December }+ \text { rice husk } \\
\text { mulching }\end{array}$ & 5.133 & 385.01 & 12.08 & 53.79 & 63.78 & 64.42 \\
\hline $\begin{array}{l}\mathrm{T}_{7}-1 \mathrm{st} \text { December }+ \text { wheat } \\
\text { straw mulching }\end{array}$ & 5.166 & 387.46 & 13.61 & 54.41 & 64.15 & 65.17 \\
\hline $\begin{array}{l}\mathrm{T}_{8}-15 \text { th } \text { December }+ \text { no } \\
\text { mulching }\end{array}$ & 3.030 & 227.22 & 9.42 & 46.82 & 57.29 & 58.09 \\
\hline $\begin{array}{l}\mathrm{T}_{9}-15 \text { th December }+ \text { saw dust } \\
\text { mulching }\end{array}$ & 3.310 & 248.26 & 12.45 & 48.52 & 58.15 & 59.22 \\
\hline $\begin{array}{l}\mathrm{T}_{10}-15 \text { th December }+ \text { rice } \\
\text { husk mulching }\end{array}$ & 3.272 & 245.41 & 12.80 & 48.19 & 58.15 & 58.82 \\
\hline $\begin{array}{l}\mathrm{T}_{11}-15 \text { th December }+ \text { wheat } \\
\text { straw mulching }\end{array}$ & 3.271 & 245.31 & 12.40 & 49.00 & 59.17 & 60.14 \\
\hline $\begin{array}{l}\mathrm{T}_{12}-30 \text { th December }+ \text { no } \\
\text { mulching }\end{array}$ & 2.191 & 164.30 & 9.11 & 38.47 & 48.34 & 49.57 \\
\hline $\begin{array}{l}\mathrm{T}_{13}-30 \text { th December }+ \text { saw dust } \\
\text { mulching }\end{array}$ & 2.278 & 170.84 & 11.04 & 42.15 & 51.90 & 52.49 \\
\hline $\begin{array}{l}\mathrm{T}_{14}-30 \text { th December }+ \text { rice } \\
\text { husk mulching }\end{array}$ & 2.287 & 171.53 & 10.61 & 41.55 & 51.19 & 51.85 \\
\hline $\begin{array}{l}\mathrm{T}_{15}-30 \text { th December }+ \text { wheat } \\
\text { straw mulching }\end{array}$ & 2.309 & 173.15 & 10.91 & 42.16 & 51.86 & 52.51 \\
\hline \multicolumn{7}{|l|}{$\operatorname{SEm}( \pm)$} \\
\hline $\mathrm{D}$ & 1.12 & 1.12 & 0.35 & 0.78 & 0.78 & 0.76 \\
\hline M & 0.07 & 0.07 & 0.05 & 0.01 & 0.08 & 0.11 \\
\hline DXM & 0.07 & 0.07 & 0.02 & 0.01 & 0.06 & 0.09 \\
\hline \multicolumn{7}{|l|}{$\mathrm{CD}(\mathrm{P}=0.05)$} \\
\hline $\mathrm{D}$ & 2.35 & 2.35 & 0.73 & 1.63 & 1.62 & 1.59 \\
\hline M & 0.14 & 0.14 & 0.11 & 0.02 & 0.17 & NS \\
\hline DXM & 0.32 & 0.32 & 0.08 & 0.04 & 0.28 & NS \\
\hline
\end{tabular}

date of transplanting with rice husk mulching, while, it was maximum under $\mathrm{T}_{4}$ at $60 \mathrm{DAT}$ (considering without mulching) and under $\mathrm{T}_{7}$ with wheat straw mulching (considering treatment with mulching). Similarly, the minimum length of leaves was also recorded under $\mathrm{T}_{4}$ as without mulching and $\mathrm{T}_{6}$ with rice husk mulching at 30 DAT. But, at 60 and 90 DAT the highest length of leaves (46.46 cm, and $56.07 \mathrm{~cm}$, respectively) was observed in the treatment $\mathrm{T}_{7}$ (transplanting at $1^{\text {st }}$ December with chopped wheat straw mulching). Rahman et al. (2013), Raut et al. (2009) also found that mulching with water hyacinth increased the growth and yield of onion followed by rice straw mulch.

The neck thickness (Table 1) was measured maximum 
Table 3. Response of various dates of planting and mulching on bulb quality of onion.

\begin{tabular}{|c|c|c|c|c|}
\hline Treatments & $\begin{array}{l}\text { TSS } \\
\left({ }^{0} \mathrm{~B}\right)\end{array}$ & $\begin{array}{c}\text { Total sugars } \\
(\%)\end{array}$ & $\begin{array}{c}\text { Reducing } \\
\text { sugar }(\%)\end{array}$ & $\begin{array}{c}\text { Non reducing } \\
\text { sugar (\%) }\end{array}$ \\
\hline $\mathrm{T}_{0}-15$ th November + no mulching & 11.73 & 8.81 & 4.78 & 4.03 \\
\hline $\mathrm{T}_{1}-15$ th November + saw dust mulching & 12.61 & 9.97 & 5.49 & 4.47 \\
\hline $\mathrm{T}_{2}-15$ th November + rice husk mulching & 13.74 & 10.08 & 5.88 & 4.20 \\
\hline $\mathrm{T}_{3}-15$ th November + wheat straw mulching & 13.37 & 10.19 & 5.88 & 4.31 \\
\hline $\mathrm{T}_{4}-1$ st December + no mulching & 12.80 & 8.38 & 4.73 & 3.66 \\
\hline $\mathrm{T}_{5}-1$ st December + saw dust mulching & 12.93 & 9.28 & 5.19 & 4.09 \\
\hline $\mathrm{T}_{6}-1$ st December + rice husk mulching & 13.57 & 10.16 & 5.69 & 4.47 \\
\hline $\mathrm{T}_{7}-1$ st December + wheat straw mulching & 13.84 & 10.39 & 5.91 & 4.48 \\
\hline $\mathrm{T}_{8}-15$ th December + no mulching & 11.93 & 8.36 & 4.78 & 3.58 \\
\hline $\mathrm{T}_{9}-15$ th December + saw dust mulching & 11.99 & 9.26 & 5.51 & 3.74 \\
\hline $\mathrm{T}_{10}-15$ th December + rice husk mulching & 12.74 & 9.48 & 5.40 & 4.09 \\
\hline $\mathrm{T}_{11}-15$ th December + wheat straw mulching & 11.88 & 9.09 & 5.43 & 3.65 \\
\hline $\mathrm{T}_{12}-30$ th December + no mulching & 11.61 & 8.12 & 4.60 & 3.52 \\
\hline $\mathrm{T}_{13}-30$ th December + saw dust mulching & 11.14 & 8.58 & 5.02 & 3.56 \\
\hline $\mathrm{T}_{14}-30$ th December + rice husk mulching & 11.58 & 8.88 & 5.30 & 3.58 \\
\hline $\mathrm{T}_{15}-30$ th December + wheat straw mulching & 12.17 & 8.59 & 5.00 & 3.59 \\
\hline \multicolumn{5}{|l|}{$\operatorname{SEm}( \pm)$} \\
\hline $\mathrm{D}$ & 0.41 & 0.39 & 0.26 & 0.29 \\
\hline M & 0.16 & 0.07 & 0.18 & 0.27 \\
\hline DXM & 0.07 & 0.03 & 0.05 & 0.08 \\
\hline \multicolumn{5}{|l|}{$\mathrm{CD}(\mathrm{P}=0.05)$} \\
\hline $\mathrm{D}$ & 0.85 & 0.82 & 0.55 & 0.60 \\
\hline M & 0.34 & 0.14 & 0.38 & 0.57 \\
\hline DXM & 0.29 & 0.12 & 0.21 & 0.34 \\
\hline
\end{tabular}

under $\mathrm{T}_{5}$ at $30 \mathrm{DAT}$, but it increased better at later stage of growth by $\mathrm{T}_{7}$ at 60 and 90 DAT among all treatments under study. It was found that $T_{7}$ and $T_{6}$ proved to be the best for vegetative growth. Whereas, the late planting had bad effect on growth. The late planting with or without mulching sometimes showed performance even poorer that control.

The increase in plant height, number of leaves, length of leaves and neck thickness of onion under mulching conditions might be due to the availability of more amount of soil moisture, temperature and humidity due to mulching. It is established that mulching is an advantageous tool for the conserving soil moisture and thus, get the positive and significant result in the case of vegetative growth characters. The yield of onion also depends on vegetative growth before commencement of bulbing (Al-Moshileh, 2007, Derawadan et al., 2002 and Adekpe et al., 2007) .

When no mulching was considered, the maximum basal diameter $(11.65 \mathrm{~mm})$ was recorded under $\mathrm{T}_{4}$ without application of mulching at first date of transplanting (Table 2). Late transplanting caused deterioration on growth and recorded minimum basal diameter $(9.11 \mathrm{~mm})$ under $\mathrm{T}_{12}$ (Control). Similarly, polar diameter $(50.96 \mathrm{~mm})$ was also measured maximum under treatment $T_{7}$ fallowed by treatment $T_{5}$ (first date of transplanting with saw dust mulching). When mulching was not applied the first date of transplanting $\left(\mathrm{T}_{4}\right)$ was found better to get maximum equatorial diameter $(60.21 \mathrm{~mm})$ and $\mathrm{T}_{7}$ (transplanting on $1^{\text {st }}$ December with 


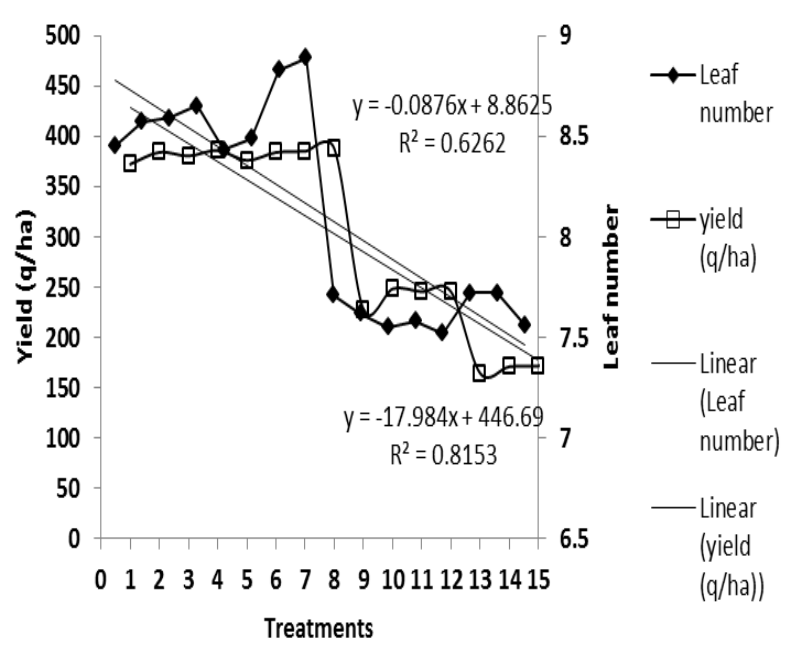

(a)

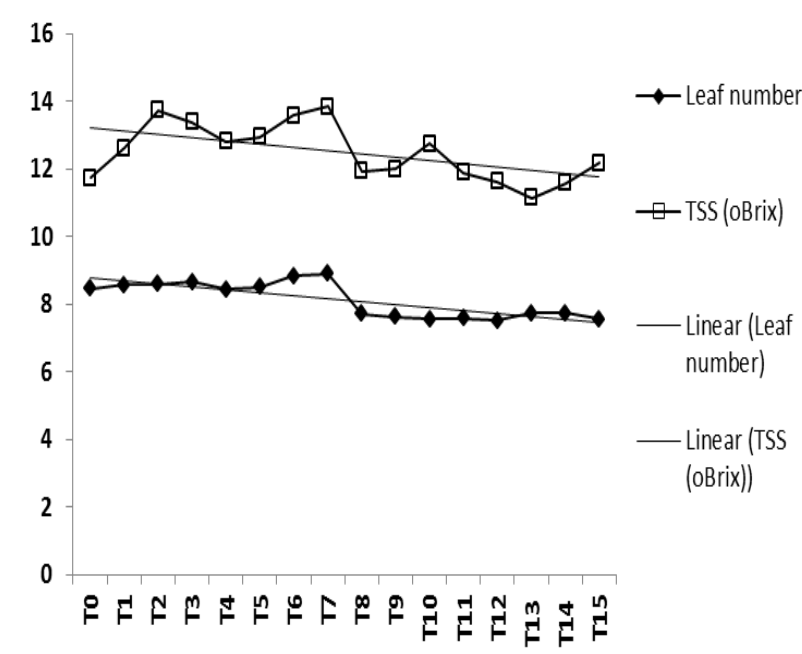

(b)

Fig 1. Relation between leaf number with yield (a) and TSS (b)

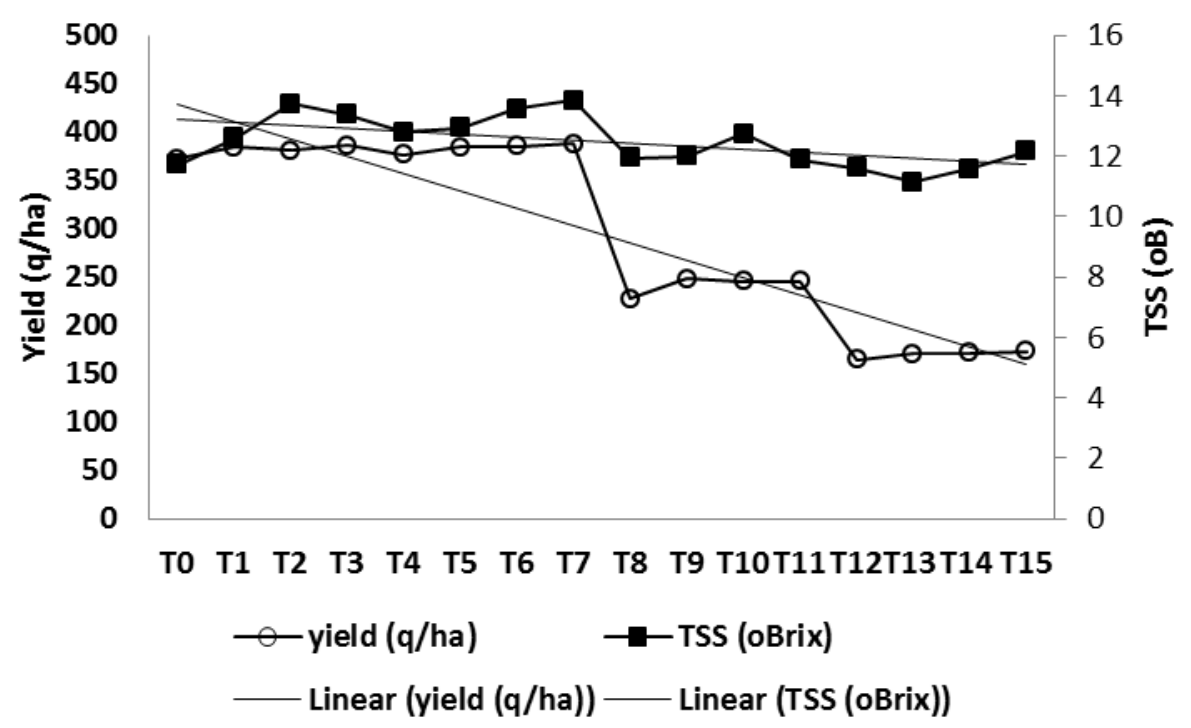

Fig 2. Relation between bulb yield and TSS.

chopped wheat straw mulching) recorded maximum equatorial diameter $(64.15 \mathrm{~mm})$. The minimum equatorial diameter was recorded $(48.34 \mathrm{~mm}) \mathrm{T}_{12}$ without any mulching at the third date of transplanting which was late. Likewise, the bulb length was found maximum $(65.17 \mathrm{~mm})$ under the treatment $\mathrm{T}_{7}\left(1^{\text {st }}\right.$ December transplanting and wheat straw mulching) and the minimum $\left(49.57 \mathrm{~mm}\right.$ ) was recorded under $\mathrm{T}_{12}$ (without any type of mulching). This result was also supported by the work of Singh (2005) who worked on effect of date of transplanting and spacing on onion and reported that transplanting on $11^{\text {th }}$ October followed by $1^{\text {st }}$ October was the best for higher growth and yield. The mulching with wheat straw and first date of transplanting $\left(\mathrm{T}_{7}\right)$ also increased the number of scales per bulb which was maximum (9.27) among all the treatments. Hygrotech (2010) also noted similar trend in production guidelines of onion.
Effect of different date of transplanting and mulching on yield of onion: The data in Table 2 revealed that the highest yield $(387.46 \mathrm{q} / \mathrm{h})$ was obtained from $\mathrm{T}_{7}$ (transplanting on $1^{\text {st }}$ December with chopped wheat straw mulching) followed by $\mathrm{T}_{3}$ (transplanting on $15^{\text {th }}$ November with chopped wheat straw mulching). The lowest yield $\left(164.30 \mathrm{q} / \mathrm{h}\right.$ ) was obtained in $\mathrm{T}_{12}$ (third date transplanting without mulching). Thus, transplanting on $1^{\text {st }}$ December was better than other date of transplanting irrespective of mulching materials and mulching with wheat straw increased the yield of onion and found as the best when it was done at $1^{\text {st }}$ December $\left(\mathrm{T}_{7}\right)$. Gupta and Gupta (1987) also found that mulching and soil moisture retention caused yield of tomato and okra and guava (Maji and Das, 2008 a,b).

Effect of different date of transplanting and mulching on bio-chemical parameters of onion: It was found that highest total soluble solids $\left(13.84^{\circ} \mathrm{Brix}\right)$ was 
recorded under the treatment $T_{7}$ fallowed by $T_{2}$. If no mulching was applied then $\mathrm{T}_{4}$ was better to record the highest TSS $\left(12.80^{\circ} \mathrm{B}\right)$. Mulching increased TSS content in general and the better TSS by mulching might be due to more assimilation of nutrients and better soil moisture as observed by Olfati et al. (2008) in carrot. Khan et al. (2013) also reported the beneficial effect of soil surface management by mulching while experimented on peanut production. Similarly, ascorbic acid $(10.47 \mathrm{mg} / 100 \mathrm{~g})$ content was also increased due to wheat straw mulching at transplanting on $1^{\text {st }}$ December $\left(\mathrm{T}_{7}\right)$ and poor performance was found by late transplanting i.e. $\mathrm{T}_{12}$. Najafabadia et al. (2012) mulching helped to get better yield of garlic in rice field as second crop. Similar trend was also found in case of sugar total sugar reducing and non reducing sugar which were also reported by Mohanty (2001), who observed taller plants with maximum leaves, yield and quality when planted on $15^{\text {th }}$ November. It was also revealed that the TSS and bulb yield were positively correlated with leaf number i.e. vegetative growth in terms of leaf number also enhanced yield and bulb TSS (Fig. 1) whereas, TSS and yield did not follow similar pattern among themselves (Fig. 2). Delay planting affected badly mostly by chilling low temperature at the early stages of growth as well as dry hot summer during bulbing period.

\section{Conclusion}

Considering all the performances and recorded observations it might be concluded that the transplanting on $1^{\text {st }}$ December followed by $15^{\text {th }}$ November and in combination with wheat straw mulching $\left(\mathrm{T}_{7}\right)$ might be suggested for getting more growth, more as well as good quality bulb. Because transplanting on 1st December with wheat straw mulching helped to produced more vegetative growth, bulb yield and improve quality as compared to other mulching. In respect of date of transplanting, transplanting on $1^{\text {st }}$ December along with chopped wheat straw mulching showed better plant height (65.34 $\mathrm{cm}$ at $90 \mathrm{DAT})$, number of leaves (8.89/plant at $90 \mathrm{DAT})$, neck thickness $(18.75 \mathrm{~mm})$, bulb yield $(387.46 \mathrm{q} / \mathrm{ha})$, bulb diameter $(13.61 \mathrm{~mm})$, TSS $\left(13.84{ }^{0} \mathrm{~B}\right)$, total sugars $(10.39 \%)$ etc. compared to all treatments. Delay in transplanting caused negative effect on its growth, yield and quality.

\section{REFERENCES}

A. O. A. C. (2000). Vitamins and other nutrients In: Official Methods of Analysis of AOAC International. Association of Official Methods of Agricultural Chemists. $\left(17^{\text {th }}\right.$ ed.), Washington, D.C. pp.16-20.

Abbey, L. and Joyce, D. C. (2004). Water deficit stress and soil type effects on spring onion growth. Journal of Vegetable Crop Production, 10: 5-18.

Adekpe, D. I., Shebayan, J. A. Y., Chiezey, U. F. and Miko, S. (2007). Yield responses of garlic (Allium sativum L.) to oxidation, date of planting and intra-row spacing under irrigation at Kadawa, Nigeria. Crop Protection. 26 (12): 1785-1789.

Al-Moshileh, A. M. (2007). Effects of Planting Date and Irrigation Water Level on Onion (Allium cepa L.) Production Under Central Saudi Arabian conditions. Scientific Journal of King Faisal University (Basic Appl. Sci.). 8(1) :1428

Anonymmous (2014). NHB Database 2014. Ministry of Agriculture, Government of India. nhb.gov.in/area-pro/ NHB Database 2014.pdf. pp. 10 -29.

Anonymmous (2015). NHB Database 2015. Ministry of Agriculture, Government of India. nhb.gov.in/area-pro/ NHB Database 2015.pdf. pp. 114-119.

Aykroyd, W. R. (1963). ICMR. Special Report, Series, No. 42.

Brewster, J. L. (2008). Onions and other vegetable Alliums. $2^{\text {nd }}$ edition. $C A B$ International, Wallingford, United Kingdom.

Derawadan, S. A., Tahir, M. and Khan, A. A. (2002). Date of sowing and genotype interaction effect on the bulb yield of transplanted onion (Allium sativum L.). Asian Journal of Plant Science. 1 (6): 675-677.

Duke, J. A. and Ayensu, E. S. (1985). Medicinal Plants of China. Reference Publications, Inc. p.705 .

Griffiths, G., Trueman, L., Crowther, T., Thomas, B. and Smith, B. (2002). Onions a global benefit to health. Phytotherapy Research, 16: 603-615.

Gupta, J. P. and Gupta, G. N. (1987). Response of tomato and okra crops to irrigation and mulch in arid region of India. Agrochemicals, 31: 183-202.

Hasegawa, A., Yabuki, H., Nabeura, T., Fukui, H. and Iwata, T. (2001). Evaluation of bulb shape and fresh-weight of different onion cultivars. Technical Bulletin Agriculture, Kagawa University. 53: 71-77.

Hygrotech (2010). Production guidelines of onions. Hygrotech Sustainable Solutions. Hygrotech, Pretoria, South Africa.

Jilani, M.S. and Ghaffoor, A. (2003). Screening of local varieties of onion for bulb formation. International Journal of Agriculture and Biology, 5: 129-133.

Khan, A. R., Rahman, A. and Singh, R.D. (2013). Influence of soil surface manipulation on soil temperature in relation to peanut production. Journal of Applied and Natural Science, 5(1): 53-57

Maji, S. (2013). Different Farming Options to Reduce Pesticide Load in Crop and Environment. In: Green Chemistry and sustainable Agriculture Practices: a Step towards a Better Future, Ed.- Dr. T. Chattopadhyay and Dr. B. Bhowmik. Pub: Council for MS Academic. 45$65 \mathrm{pp}$.

Maji, S. and Das, B. C. (2008a). Effect of organic and inorganic mulches on vegetative growth and yield of guava cv. L-49. Environment and Ecology, 26(3A) :1292-1293

Maji, S. and Das, B. C. (2008b). Response of mulching on fruit quality and yield of guava (Psidium guajava L.). Environment and Ecology, 26(4): 1630-1631

Mallor, C., Carravedo, M., Estapanan, G. and Mallor, F. (2011). Characterization of genetic resources of onion (Allium cepa L.) from the Spanish secondary centre of diversity. Spanish Journal of Agricultural Research, 9 (1):144-155

Mohanty, B. K. (2001). Performance of common onion varieties in Kharif seasons. Journal of Tropical Agriculture, 
39: 21-23.

Najafabadia, M. B., Mahdieh, G. H. Peyvasta, M. Hassanpour Asila, J. A. Olfatia and M. Rabieeb (2012) Mulching effects on the yield and quality of garlic as second crop in rice fields. International Journal of Plant Production, 6(3): 279-290.

Olfati, J. A. _ Peyvast, G. and Nosrati-Rad, Z. (2008). Organic mulching on carrot yield and quality. International Journal of Vegetable Science, 14(4):362-368.

Panse, V. G. and Sukhatme, P. V. (1985). In: Statistical Methods for Agricultural Workers. ICAR, New Delhi.

Perane, R. R. (2001). Studies on purple blotch of onion caused by Alternaria Cepulicola Rao with reference to toxin production of the pathogen. Mahatma Phule Krishi Vidyapeeth. http://krishikosh.egranth.ac.in/ handle/1/15122

Rahman, M. A., Mahmud, J. A. and Islam, M. M. (2013). Influence of mulching on the growth and yield of onion. Technical Journal of Engineering and Applied Science, 3(24): 3497-3501
Raut, D. B., Dhonde, M. B. and Gaikwad, C. B. (2009). Growth and yield of Rabi onion (Allium cepa L.) influenced by mulch and potash levels. Journal of Maharashtra Agriculture University, 34(2): 224-225

Singh, A. and Korla, B.N. (1991). Effect of transplanting dates and varieties on number of leaves and yield in onion. Vegetable Science, 18(1): 24-28

Singh, A. (2005). Effect of planting time, bulb size and bulb spacing on plant growth and seed yield attributes of onion. Indian Journal of Horticulture, 69-73

Umar, M. S., Muoneke, C. O. and Magaji, M. D. (2000). Effect of intra-row spacing and mulching materials on growth and yield of onion (Allium cepa L.). Nigeria Journal of Agriculture Environment, 1(2)

Zohary, D. and Hopf, M. (2000). Domestication of plants in the old world (Third Ed.). Oxford: Oxford University Press. p.198 . Yilmaz, I. (2004). Effect of rye bran addition on fatty acid composition and quality characteristics of low fat meat balls. Meat Sci., 67(2: 245-249 